\title{
ABERRANT TEXTUALITY? \\ THE CASE OF EZEKIEL THE (PORNO) PROPHET
}

Andrew Sloane

\begin{abstract}
Summary
'Pornoprophetic' readings of the unfaithful wife metaphors in Hosea 1-3, Jeremiah 2 and 3, and Ezekiel 16 and 23 criticise them as misogynistic texts that express and perpetuate negative images of women and their sexuality. This study seeks to present an evangelical response to Athalya Brenner and Fokkelien van Dijk-Hemmes' pornoprophetic reading of Ezekiel 16 and 23. I outline their claims and supporting arguments, including their assertion that the texts constitute pornographic propaganda which shapes and distorts women's (sexual) experience in the interests of male (sexual) power. I argue that both their underlying methods and assumptions and their specific claims are flawed, and so their claims should be rejected. While acknowledging the offensive power of the texts, I conclude that alternative explanations such as the violence of Israel's judgement and the offensive nature of Jerusalem's sin account better for the features of the texts which they find problematic.
\end{abstract}

\section{Introduction}

The Old Testament prophets have been an important resource in Christian ethics, particularly in relation to understanding God's passion for justice-and his corresponding passion that his people reflect that in the conduct of their lives and the patterns of their communities. A recent movement of evangelicals engaging with social justice and advocacy on behalf of the poor derives its name from Micah's call to 
justice (Micah 6:6-8). ${ }^{1}$ Ezekiel's vision of a new Jerusalem is a vital resource in Revelation's vision of the new heavens and earth where, in the words of Peter, righteousness is at home (2 Pet. 3:13). ${ }^{2}$ What are we to do, then, when the very ethics of the prophets is called into question or when they are criticised as oppressive, violent, misogynist and abusive? Such charges, if substantiated, would vitiate their use in Christian ethics and call into question evangelical views of the nature and function of Scripture. Athalya Brenner and Fokkelien van DijkHemmes' pornoprophetic critique of Ezekiel (and Hosea and Jeremiah) present a substantial challenge to (evangelical) Christian use of the prophets as a resource in Christian ethics. And theirs are not isolated voices. Their views are either reflected and endorsed or echoed in the work of many others, ${ }^{3}$ and have been echoed in the responses of

1 The Micah Challenge and associated Micah Network. Details can be found on their respective websites, <http://www.micahnetwork.org/> [accessed 17/08/2007] and $<$ http://www.micahchallenge.org/> [accessed 17/08/2007].

2 It is also interesting to note in this regard that his description of Sodom's sin in Ezek. 16:49-50 focuses on abuse and neglect of the poor.

3 For the endorsement of their views, see Mieke Bal, 'Foreword' in On Gendering Texts: Female and Male Voices in the Hebrew Bible, eds. Athalya Brenner and Fokkelien van Dijk-Hemmes (Leiden: Brill, 1993): ix-xiii [a glowing endorsement of the book]; J. Cheryl Exum, 'The Ethics of Biblical Violence Against Women' in The Bible in Ethics, eds. J. W. Rogerson et al. (Sheffield: Sheffield Academic, 1995): 24871; Pamela Gordon and Harold C. Washington, 'Rape as a Military Metaphor in the Hebrew Bible' in A Feminist Companion to the Latter Prophets, ed. A. Brenner (Sheffield: Sheffield Academic, 1995): 308-25; cf. F. Rachel Magdalene, 'Ancient Near Eastern Treaty-Curses and the Ultimate Texts of Terror: A Study of Divine Sexual Abuse in the Prophetic Literature' in A Feminist Companion to the Latter Prophets, ed. A. Brenner (Sheffield: Sheffield Academic, 1995): 326-52; Phyllis Bird, 'Poor Man or Poor Woman? Gendering the Poor in Prophetic Texts' in On Reading Prophetic Texts, ed. R. Becking and M. Dijkstra (Leiden: Brill, 1996): 37-49; Deryn Guest, 'Hiding behind the Naked Woman: A Recriminative Response', Biblical Interpretation 7.4 (1999): 413-48; Gale Yee, Poor Banished Children of Eve: Woman as Evil in the Hebrew Bible (Minneapolis: Fortress, 2003). For analyses of these texts that, while not specifically citing their work, clearly echo their methods and conclusions, see, Katherine Pfisterer Darr, 'Ezekiel's Justification of God: Teaching Troubling Texts', JSOT 55 (1992): 97-117; Marvin H. Pope, 'Mixed Marriage Metaphor in Ezekiel 16' in Fortunate the Eyes that See, ed. A.B. Beck et al. (Grand Rapids: Eerdmans, 1995): 384-99; Renita J. Weems, Battered Love: Marriage, Sex, and Violence in the Hebrew Prophets (Minneapolis: Fortress, 1995); Carol J. Dempsey, 'The 'Whore' of Ezekiel 16: The Impact and Ramifications of GenderSpecific Metaphors in Light of Biblical Law and Divine Judgment' in Gender and Law in the Hebrew Bible and the Ancient Near East, ed. V. H. Matthews et al. (Sheffield: Sheffield Academic, 1998): 57-78; Mary Shields, 'Gender and Violence in Ezekiel 23', SBL Seminar Papers no. 37, part 1 (Atlanta: Scholars, 1998): 86-105; Mary Shields, 'Multiple Exposures: Body Rhetoric and Gender Characterization in Ezekiel 16', Journal of Feminist Studies in Religion 14.1 (2004): 5-18. 
'ordinary readers' to the texts. ${ }^{4}$ Thus, whilst evangelical scholars have not extensively analysed their work, it is important to do so, lest we neglect important issues in Old Testament interpretation and Christian ethics and fail to address significant ministry issues. ${ }^{5}$ In this paper, then, I will begin by outlining Brenner and van Dijk-Hemmes' case, paying particular attention to Ezekiel 16 and 23. This will entail presenting their main conclusions and identifying what they take to be the justification of their position. I will then present an analysis of their claims, dealing with their assumptions and methodology, as well as their key evidence and arguments. In so doing I will appraise them from an evangelical perspective, present alternative explanations of key aspects of the texts and note in passing implications for our dealing with texts such as these.

\section{Athalya Brenner, Fokkelien van Dijk-Hemmes and Pornoprophetics}

\section{2:1 Their case}

The metaphors of the adulterous wife in Ezekiel 16 and 23 confront us with a shocking depiction of the sinful rebellion of God's people. Given the explicit nature of Ezekiel's language, it is not surprising that readers, especially women, might be offended by the text. Brenner and van Dijk-Hemmes argue that our reaction should go beyond shock and offence to outright rejection of the text. Texts such as Ezekiel 16 and 23 are examples of what could be called 'aberrant textuality'-texts that express and foster misogynist views of women and their sexuality and perpetuate sexual violence against them. They are pornographic in their presentation of women and women's sexuality and as such are not worthy to be treated as sacred Scripture - indeed they must be resisted

\footnotetext{
4 For instance, my eldest daughter, Elanor (then 15) found the metaphors offensive and misogynistic on first reading.

5 Christopher Wright, Old Testament Ethics for the People of God (Leicester: IVP, 2004): fn.13, p. 448, has noted the need for a careful evangelical study of these issues (admittedly, specifically referring to Cheryl Exum's work cited above). Brief discussions of pornoprophetics can be found in Raymond C. Ortlund Jr, 'Appendix' in Whoredom: God's Unfaithful Wife in Biblical Theology (Leicester: Apollos, 1996): 177-85; Daniel I. Block, 'Excursus: The Offense of Ezekiel's Gospel' in The Book of Ezekiel: Chapters 1-24 (Grand Rapids: Eerdmans, 1997): 467-71, neither of which adequately addresses underlying methodological and hermeneutic issues.
} 
as damaging to women and their interests. For instance, Brenner claims that 'the twin image of the divine husband (YHWH) and his errant, promiscuous wife... is a propaganda device which is pornographic in nature because of the female exposure and sexual violence against women that it builds on and even advocates, and because of its methods of persuasion.' ${ }^{6}$

Texts such as these are damaging to women in the ways in which they function in religious communities. Brenner states: 'Biblical pornography has been utilized as an extremely effective vehicle for the fossilization of gender roles because it carries a unique authority even when not acknowledged as such.' 7 These texts, furthermore, address women in particular (harmful) ways, and in a manner distinct from how they address men. Van Dijk-Hemmes argues that while the metaphor in Ezekiel 23 humiliates both men and women, men are given a way of escape by way of identification with either the husband, Yahweh, or the righteous men of v. 45 . This route is not available to women, who are specifically and directly spoken against at the end of the text which thereby both misrepresents women's experience and distorts their sexuality. ${ }^{8}$

In the same vein Brenner claims that the 'prophetic' metaphors (including Ezekiel's) are the ultimate expression of fantasies of male domination with God, the male, being in absolute authority over the totally submissive female. Because of its psychological origins in male insecurity, this is not 'just' a metaphor, but is an expression of a pornographic vision. ${ }^{9}$

A (male) fantasy of (male) domination is acted out by equating divine authority with male power. The (male) fantasy of (female) submission becomes definitive. It is easily legitimized by a two-way application of the analogy: when God is imaged as a human male, human males can be

6 Athalya Brenner, The Intercourse of Knowledge: On Gendering Desire and 'Sexuality' in the Hebrew Bible (Leiden: Brill, 1997): 7.

7 Athalya Brenner, 'Introduction' in On Gendering Texts: Female and Male Voices in the Hebrew Bible, Athalya Brenner and Fokkelien van Dijk-Hemmes (Leiden: Brill, 1993): 1-13, quotation from page 12.

8 Brenner, 'Introduction': 176.

9 Athalya Brenner, 'On “Jeremiah" and the Poetics of (Prophetic?) Pornography' in On Gendering Texts: Female and Male Voices in the Hebrew Bible, Athalya Brenner and Fokkelien van Dijk-Hemmes (Leiden: Brill, 1993): 177-93, quotation from page 189. 
viewed as divine... Metaphor creates its own 'reality', its own frame of reference, not to mention hierarchy. ${ }^{10}$

This is a dangerous and destructive reality, one abusive of women:

This propaganda cleverly constructs a stereotype: everywoman, especially everywife, is a potential deviant and should therefore be tightly controlled. By males, of course. Wife-abuse and rape should be directly linked to the worldview which makes such prophetic propaganda acceptable. Religious-political propaganda can lead to wholesale rape of women: read the news about Bosnia. ${ }^{11}$

She concludes 'that whoever composed those passages perceived women and men - not to mention God-and gender relations in a certain way. That vision, that male fantasy of desire which presupposes a corresponding and complementary mythical fantasy of female desire, is pornographic. As a reader, I can resist this fantasy by criticism and reflection. ${ }^{12}$

\section{2:2 Their evidence and arguments}

Their primary evidence comes from an interpretation of the text driven by a particular interpretive stance. ${ }^{13}$ The influence of that stance, particularly on what counts as evidence from the text to support their conclusions, is evident in relation to the 'pornographic' elements in the text. Brenner argues that the very language used in the metaphors is problematic, given the associations of the root זr (zanah, to be [sexually] unfaithful): 'the use of the same verbal sequence for designating female prostitution and promiscuity on the one hand, and for designating male illegitimate religious beliefs and practices on the

10 Athalya Brenner, 'On Prophetic Propaganda and the Politics of "Love": The Case of Jeremiah' in A Feminist Companion to the Latter Prophets, ed. A. Brenner (Sheffield: Sheffield Academic, 1995): 256-74, quotation from pages 270-71. This is a slightly modified later version of 'Poetics of Pornography' cited above.

11 Brenner, 'On Prophetic Propoganda': 273.

12 Brenner, 'Poetics of Pornography': 193. This is their conclusion both severally and together; in their joint conclusion to their work on pornoprophetics they claim that biblical pornography is potentially more dangerous than other forms of pornography inasmuch as the male vision of the text can be covertly equated with God's own view of women and their sexuality, requiring our resistance to such violent authoritarian control. See Athalya Brenner and Fokkelien van Dijk-Hemmes, 'Afterword' in On Gendering Texts: Female and Male Voices in the Hebrew Bible, Athalya Brenner and Fokkelien van Dijk-Hemmes (Leiden: Brill, 1993): 194-95.

13 Of course, all reading comes from an interpretive point of view; my criticism below is in relation to the nature and validity of the 'pornoprophetic' point of view, not the fact that they have one. 
other hand, establishes an unmistakable association that is hardly complementary [sic] to women and their sexual behaviour'. ${ }^{14}$ She asserts, furthermore, that the 'textual voice' is gendered as a male voice, which speaks to human social and sexual relations. "The message, although indirect, is clear. "Wifely" loyalty is to be learnt through re-education and punishment, including exposure and public shaming.' ${ }^{15}$ Indeed, this male voice is also the voice of God, demonstrating 'male authority as symbolized by and symbolizing divine authority'. ${ }^{16}$

She makes similar points about the treatment of the male and female body, especially in the prophets. She argues that circumcision establishes a clear connection between the penis and the divine so that: 'women are excluded a priori from this symbolic order... bonding with the (male) god is stamped on the (male) body.' ${ }^{17}$ Furthermore, the penis is afforded protection not offered the female body in the 'so-called prophets' where female bodies are repeatedly exposed and threatened. ${ }^{18}$ In the " "prophetic" vision' in Ezekiel 23, 'the elusive demarcation lines between metaphor and "reality" break down and the two worlds, the divine/human and the social, blur into one gendered schism.' 19 'What we, all of us, ultimately see in the woman-community of the divine husband/human wife metaphor is not just a metaphorical woman but a naked woman - silent, accused of prostitution, framed for sustaining male violence.' ${ }^{20}$ She rejects this 'pornographic fantasy of male desire'. ${ }^{21}$

Their reading of Ezekiel also draws on their analysis of other 'pornoprophetic' texts. For instance, van Dijk-Hemmes sees Hosea as 'extolling an ideal patriarchal marriage in which the woman has to submit to her husband and remain faithful to him', ${ }^{22}$ which informs her reading of Ezekiel 23. The latter text also 'speaks not only of women, but also - albeit indirectly - specifically to women'. ${ }^{23}$ It refers not only

\footnotetext{
14 Brenner, Intercourse of Knowledge: 148.

15 Brenner, 'Pornoprophetics Revisited': 253.

16 Brenner, 'Pornoprophetics Revisited': 266.

17 Brenner, 'Pornoprophetics Revisited': 269.

18 Brenner, 'Pornoprophetics Revisited': 266-71.

19 Brenner, 'Pornoprophetics Revisited': 272.

20 Brenner, 'Pornoprophetics Revisited': 272.

21 Brenner, 'Pornoprophetics Revisited': 273.

22 Van Dijk-Hemmes, 'Metaphorization', On Gendering Texts: 168.

23 Van Dijk-Hemmes, 'Metaphorization', On Gendering Texts: 169, 170.
} 
(or even primarily) to the religious and political condition of Israel around the time of the exile, but to Israelite social and sexual realities. Thus, references in the text to the treatment of the metaphorical women become references to the expected treatment of actual women in the social world of ancient Israel: the deity's control over the city in grace, indictment, punishment and restoration reflects and endorses the control that men in Israel had (and should have) over women and their sexuality. ${ }^{24}$

Related to this is their understanding of the role of gender and sexuality in ancient Israelite society and the Hebrew Bible. Brenner sees desire and sexuality as strongly 'gendered' in the Hebrew Bible, as reflected both in linguistic and textual data.25 "The Hebrew word for "male"... is זכר [z-k-r], apparently from a root denoting "to remember"... A female... is designated by נקבה [n- $[n-b-h]$, derived from a consonantal sequence designating "pierce, make a hole" (Qal) and formally constituted as the grammatical F formation of נקב [n-qb], "hole", "cavity", “opening", "orifice". 26 Etymology informs meaning and so:

A 'female' is sexed rather than gendered: she is an 'orifice'; orifices and holes require that they be filled. A 'male' is gendered: he is the carrier of memory, the one 'to be remembered', thus a social agent. The female is there to be penetrated and to be receptive... socially, there is no difference between her biological and social function. The male agent carries the burden of social continuity, of culture ('remembrance'); he is there to 'give', that is, penetrate the female 'hole' or receptacle. ${ }^{27}$

This is precisely the picture that also emerges from the key texts relating to love and desire and male and female sexuality. ${ }^{28}$ Their view of sexuality and gender in the Hebrew Bible in which women and their bodies are marginalised, subject to male power and control, informs their reading of the 'prophetic' texts and, indeed, is taken to support their conclusions. Nonetheless, the strength of their case is tied to their underlying assumptions and the methodology that informs their

24 Van Dijk-Hemmes, 'Metaphorization', On Gendering Texts: 173, 175.

25 Brenner, The Intercourse of Knowledge.

26 Brenner, The Intercourse of Knowledge: 11-12.

27 Brenner, The Intercourse of Knowledge: 12.

28 Brenner, The Intercourse of Knowledge: 13, 178. 
analysis, ${ }^{29}$ as are many of its key components. It is to those assumptions and methods that we now turn.

\section{2:3 Their methodologies and assumptions}

A key to their methodology is the use of gendered readings of biblical (and other) texts, associated with a key assumption that texts are the product of societies with particular (generally patriarchal) ideologies and that these ideologies are reflected in, perpetuated by and propounded in the text. ${ }^{30}$ For instance, the 'pornoprophetic' passages reflect $\mathrm{M}$ [masculine] voices, being 'assigned to male speakers, even specifically to the supreme authority of a male God', and expressing male 'fantasies about and against women'. ${ }^{31}$ Thus texts will knowingly or unknowingly expose the gender assumptions and gender-driven power relations of the people and communities that produced them. This belief in the inherently androcentric and oppressive nature of Israelite society and the texts it produced is so pervasive as to control their reading of the texts, including how they deal with alternative interpretations of key texts.

These assumptions and strategies are clearly associated with, and perhaps entail, a corresponding theological assumption: that these texts are not the authoritative word of God. For instance, Brenner chooses to designate the 'pornographic' texts in Jeremiah as poetry rather than prophecy in order to undermine their authority. ${ }^{32}$ Further, this is associated with a privileging of women's experience over the biblical text, as seen in her determination to "problematize the Jeremiah texts in which the husband-wife metaphor features and regard them as pornography', and to resist the text and its pornographic 'male/poet/God's viewpoint'. ${ }^{33}$

Related to this is their understanding of the nature and function of pornography, which is clearly crucial to a pornographic reading of

29 Technically, these are 'data-background' and 'control' beliefs, following the analysis of Nicholas Wolterstorff, Reason within the Bounds of Religion (2nd ed; Grand Rapids: Eerdmans, 1984). I will, however, use the looser terminology of methods and assumptions in this paper.

30 Brenner, 'Introduction', On Gendering Texts: 13. The Bible is 'a political document', containing 'ideologies of specific interest groups' ('On Prophetic Propaganda': 256; cf. The Intercourse of Knowledge: 3-4).

31 Brenner, 'Introduction', On Gendering Texts: 12.

32 Brenner, 'Poetics of Pornography': 179.

33 Brenner, 'Poetics of Pornography': 179 and 192-93. See also Brenner, 'Pornoprophetics Revisited': 273-75. 
these texts. This is derived from the work of Setel on Hosea, ${ }^{34}$ who sees 'pornography as both a description of and tool for maintaining male domination of female sexuality... through the denial, or misnaming of female experience' ${ }^{35}$ All of this is apparent in Hosea's use of female sexual imagery, ${ }^{36}$ which, in turn, makes it a pornographic view of female sexuality. Citing Setel, Brenner claims that pornography expresses "the objectification and degrading of "woman" in a manner that makes abuse of females acceptable or even commendable; that it restricts female sexual choice to an actual state of slavery; and that it stresses the nature and meaning of male power (Setel 1985, 88)... Thus pornography preserves and asserts male social domination through the control of female sexuality.' ${ }^{37}$ This is true, whatever the cultural context of the production of the texts, as contemporary and biblical pornography are significantly similar. ${ }^{38}$ 'Hence, the relevant biblical texts can be problematized as follows. If contemporary pornographic literature is found to contain anti-female bias, the same should apply to pornographic biblical literature.' 39

A similar move is made in relation to the texts' function as pornographic propaganda. Brenner's 'minimalist' definition of propaganda is 'a transaction of verbal (rhetorical) communication designed by its initiator(s) to persuade the recipients of communication to accept its message(s), then formulate new opinions, then act on the newly acquired position' ${ }^{40}$ Her definition of pornography is similarly minimalist: namely, 'the representation of sexual acts that arouses sexual excitement'. ${ }^{41}$ She identifies key (manipulative) rhetorical techniques at work in propaganda and argues that they are clearly evident in the 'so-called prophetic books'. ${ }^{42}$ Given the sexual nature of

34 T. Drorah Setel, 'Prophets and Pornography: Female Sexual Imagery in Hosea' in Feminist Interpretation of the Bible ed. L.M. Russell (Philadelphia: Westminster, 1985): 86-95; cf. van Dijk-Hemmes, 'Metaphorization': 170-71; Brenner, 'Poetics of Pornography': 181.

35 Setel, 'Prophets': 87.

36 Setel, 'Prophets': 94.

37 Brenner, 'Poetics of Pornography': 185-86.

38 Brenner, 'Poetics of Pornography': 181.

39 Brenner, 'Poetics of Pornography': 181.

40 Brenner, 'Pornoprophetics Revisited': 255.

41 Brenner, 'Pornoprophetics Revisited': 257; note the absence of questions of authorial intent.

42 Brenner, 'Pornoprophetics Revisited': 262. 
the prophets' propaganda, this is pornographic propaganda. ${ }^{43}$ 'There is no doubt that, unlike modern pornography, the pornoprophetic passages are not intended as depictions of male desire per se... That, however, is small consolation. The ideology of male supremacy is indispensable to the husband/wife metaphor: without this ideology the metaphor will not be understood, even less be acted upon.' ${ }^{44}$ Her aim is to expose and censure such violent misogynistic representations as both propaganda and pornography. ${ }^{45}$

The combination of gendered reading, ideological analysis and the identification of these texts as pornography shapes their understanding of Ezekiel 16 and 23. For instance women's experience is misnamed in Ezekiel 23:3, where women are blamed for being sexually abused in Egypt. ${ }^{46}$ Van Dijk-Hemmes states: 'Israel's sin in Egypt actually consists of its being oppressed... Within an androcentric framework women can easily be seen as guilty of their own abuse. Hence, the imagery of women is indispensable for conveying a message which is a contradiction in terms: the people are guilty of their own past enslaving inasmuch as women are, by definition, guilty of their own sexual misfortunes.' ${ }^{47}$ Their enjoyment of their violation and desiring more of it aims to convince the audience 'that both metaphorical women, so perverse since their maidenhood, deserve the utterly degrading and devastating treatment to which they are to be exposed' ${ }^{48}$

Their assumptions and methods lead to some surprising conclusions. The metaphors, while addressing Israel's religious and political faithlessness, also speak directly of women's sexuality. Van DijkHemmes states: 'Both women are degraded and publicly humiliated in order to stress that their sexuality is and ought to be an object of male possession and control.' ${ }^{49}$ Indeed, the religious and sexual functions of the text are linked:

The androcentric-pornographic character of this metaphorical language must indeed be experienced as extremely humiliating by an $\mathrm{M}$ [male] audience forced to imagine itself as being exposed to violating enemies. Nevertheless, it is exactly this androcentric-pornographic character

\footnotetext{
43 Brenner, 'Pornoprophetics Revisited': 265-66.

44 Brenner, 'Pornoprophetics Revisited': 266.

45 Brenner, 'Pornoprophetics Revisited': 274.

46 Van Dijk-Hemmes, 'Metaphorization': 172-73.

47 Van Dijk-Hemmes, 'Metaphorization': 173.

48 Van Dijk-Hemmes, 'Metaphorization': 173-75, quote from page 175.

49 Van Dijk-Hemmes, 'Metaphorization': 175.
} 
which at the same time offers the $\mathrm{M}$ audience a possibility of escape: the escape of the identification with the wronged and revengeful husband; or, more modestly, identification with the righteous men who, near the end of the text, are summoned to pass judgment upon the adulterous women (v.45)... No such possibility of escape is left to F readers. In respect to them, the metaphorization of woman in Ezekiel 23 performs first and foremost a violent speech act which is even more offensive than the Hosean version: it simultaneously shapes and distorts women's (sexual) experience. ${ }^{50}$

Brenner, similarly, argues that the 'prophetic' metaphors (including Ezekiel's) are the ultimate expression of fantasies of male domination: God, the male, is in absolute authority over the totally submissive female. ${ }^{51}$ Indeed, because 'the metaphor's ideology cuts both ways, accepting the metaphor entails endorsing patriarchy in both divine and human realms' ${ }^{52}$ Hence, the use of pornographic propaganda 'validates the metaphorized relationship between God and his community... by appealing to a familiar male view: women are by nature promiscuous, hence in need of containment'. ${ }^{53}$ This 'political and personal fantasy of controlling the female body, and female sexuality', is even more dangerous in the Bible than in general Western culture and must be resisted:

The utilization of this acceptable vision for religious purposes, the fact that female sexuality in it is not a target per se, may obscure the vision's origins while, simultaneously, lending it additional weight. Biblical pornography is therefore perhaps more dangerous than modern pornography. Almost imperceptibly we come to identify message and messenger, alleged author and authority - so much so that we have to recall contemporary analogues in order to resist the authority and violent control advocated in order not to be duped by the text's authoritative command... Exposure is a step towards undermining authority. ${ }^{54}$

50 Van Dijk-Hemmes, 'Metaphorization': 176.

51 Brenner, 'Poetics of Pornography': 189.

52 Brenner, 'On Prophetic Propaganda': 264.

53 Brenner, 'On Prophetic Propaganda': 266; cf. 270-73.

54 Brenner and van Dijk-Hemmes, 'Afterword', On Gendering Texts: 194. 


\section{Analysis}

\section{3:1 Their assumptions and methods}

Brenner and van Dijk-Hemmes' ideological-critical perspective, including their belief that the Bible has significantly contributed to Western society's limitation and distortion of women's experience, is an expression of their feminist perspective. It is, however, neither typical of feminist biblical scholarship, nor necessary to it. Feminist scholars have helped to expose the masculine bias of traditional biblical scholarship, including the way that biblical texts have been used against women and their interests; but they do not all believe that the Bible is itself misogynistic. ${ }^{55}$ Nonetheless, ideological approaches such as Brenner and van Dijk-Hemmes' have made a significant impact on contemporary biblical scholarship. ${ }^{56}$ This makes it important to examine their perspective on the Bible and its interpretation, as does the fact that it is clearly contrary to central evangelical commitmentsthe most notable being the idea that the Bible is the authoritative word of God, and that this God is a God of liberation, love and justice.

Central to ideological criticism of the Bible is the claim that, whatever texts purport to be about, they actually encode the systems of domination and control of the cultures or cultural groups that produced them. These ideologies are primarily political and economic in their interests and the texts serve to both reflect and propagate those power systems. A concern for liberation and freedom, then, is best served by

55 Feminist positions range from the acceptance of traditional construals of the Bible's authority of evangelical feminists, to the outright rejection of the Judeo-Christian tradition and its Scriptures of Post-Christian feminists. See Phyllis Trible, 'Treasures Old and New: Biblical Theology and the Challenge of Feminism' in The Open Text: New Directions for Biblical Studies?, ed. F. Watson (London: SCM, 1993): 32-56; K. Doob Sakenfeld, 'Feminist Perspectives on Bible and Theology: An Introduction to Selected Issues and Literature', Int 42/1 (Jan. 1988): 5-18; D. M. Scholer, 'Feminist Hermeneutics and Evangelical Biblical Interpretation', JETS, 30/4 (Dec. 1987): 40720; Thiselton, New Horizons: 430-39. Ronald Pierce, Rebecca Merrill Groothuis and Gordon Fee, eds, Discovering Biblical Equality: Complementarity without Hierarchy (Leicester: Apollos, 2004) present a good selection of evangelical feminist scholarship. Phyllis Trible, God and the Rhetoric of Sexuality (Philadelphia: Fortress, 1978) positively interprets a number of OT texts, including Genesis 2-3, which I analyse in my unpublished Th.D. thesis, Andrew Sloane, 'Wolterstorff, Exegetical Theorising and Interpersonal Relationships in Genesis 1-3' (Th.D. thesis, Australian College of Theology, 1994): ch. 8.

56 See the works cited above in fn 3, along with the pioneering study of Julie Galambush, Jerusalem in the Book of Ezekiel: The City as Yahweh's Wife (Atlanta: Scholars, 1992). 
exposing these ideologies and resisting their force ${ }^{57}$ In such a resistant 'reading against the grain' of the text, the intent of the biblical author governs neither the interpretation nor use of the text, as evident in Brenner and van Dijk-Hemmes' work on pornoprophetics.

Large scale interpretive and epistemological ideas are implicit in this perspective, analysis of which would take us too far afield. ${ }^{58}$ Ideological readings are, however, subject to serious question. For instance, Walhout has presented cogent arguments for the weakness of such a hermeneutic and the political presuppositions which nurture it. ${ }^{59}$ Similarly, while all texts may encode an agenda, it is not clear that all such agenda are political in nature. ${ }^{60}$ They may well be religious, artistic, philosophical, scientific, ethical, and so on; but to claim that such concerns are essentially and necessarily either intrinsically or instrumentally political in nature is either question begging or reductionist. Such agenda may well serve to foster the interests of a particular group, but this must be demonstrated rather than assumed, and it must be shown that this political agenda is either the real agenda which the other serves to mask, or a necessary correlative of it which exhaustively explains its origin and function. ${ }^{61}$ This has not been done in relation to the Bible or the book of Ezekiel in particular.

As (evangelical) Christians, furthermore, we are entitled to reject their theories just because they conflict with our understanding of

57 For these claims, see, F. Jameson, The Political Unconscious: Narrative as Socially Symbolic Act (Ithaca: Cornell University Press, 1981): 17-20, 74-102; 'The Symbolic Inference; or, Kenneth Burke and Ideological Analysis' in The Ideologies of Theory: Essays 1971-1986, Vol 1; Situations of Theory (London: Routledge, 1988): 137-52; J. B. Thompson, Studies in the Theory of Ideology (Cambridge: Polity, 1984); and in relation to biblical studies, J. M. Kennedy, 'Peasants in Revolt: Political Allegory in Genesis 2-3', JSOT 47 (1990): 3-14.

58 I have outlined such an analysis of an ideological reading of Genesis 2-3 in 'Wolterstorff, Exegetical Theorising, and Interpersonal Relationships in Genesis 1-3', ch. 9. See also the critique of ideological criticism and the hermeneutics of suspicion in Anthony Thiselton, New Horizons in Hermeneutics (Grand Rapids: Zondervan, 1992): esp. 410-70; Kevin Vanhoozer, Is There a Meaning in This Text? (Leicester: Apollos, 1998): esp. 148-95, 367-452.

59 C. Walhout, 'Marxist and Christian Hermeneutics: A Study of Jameson's The Political Unconscious', Faith and Philosophy 3/2 (April 1986): 135-56.

60 See Meir Sternberg, The Poetics of Biblical Narrative: Ideological Literature and the Drama of Reading (Bloomington: Indiana University Press, 1985): 35-37, 41, 4445.

61 Similar points are made in P. J. Riggs, Whys and Ways of Science (Carlton: Melbourne University Press, 1992): 136-70 regarding reductionist (ideological readings of the) sociology of science. 
Biblical authority. Now, this needs to be understood carefully. We are not entitled to casually disregard or reject any theory that we take to be inconsistent with our view of Scripture: for that view could be wrong, and there have been many instances where Christian views of Scripture have needed to change in light of other evidence. ${ }^{62}$ However, our beliefs that God speaks through Scripture and the human author's communicative actions, that the God who speaks is a good God, and so on, function legitimately as central assumptions in our scholarship and our living. ${ }^{63}$ As such, beliefs that conflict with them may be rejected on the grounds of that conflict, unless the nature and cogency of those beliefs require that we adjust those prior beliefs. Furthermore, if we have good reason to question those challenges to our central assumptions, then we are entitled, even obliged, to maintain those assumptions and reject what conflicts with them. ${ }^{64}$ That is the case in regard to Brenner and van Dijk-Hemmes' pornoprophetic reading of the prophets. ${ }^{65}$ It also means that we are entitled to adopt an alternative hermeneutical perspective, one, not of suspicion towards texts and their ideologies, but of critical trust which examines the texts, for all their multivalence, for what God said and is saying by way of the text.

This brings us to the question: given its potential to shock and offend (female) readers, why do the prophets use the metaphor of an adulterous wife at all? On the basis of their ideological reading of the Bible, Brenner and van Dijk-Hemmes believe that a key reason is the inherently misogynistic nature of Israelite society. This is unfounded, for a number of reasons. First, the metaphor finds its ultimate origin in the nature of the covenant and its call to exclusive allegiance. ${ }^{66}$ Israel is claimed by God as his own 'possession'; as such, he has exclusive

62 See Sloane, On Being a Christian in the Academy, (Carlisle: Paternoster, 2003): 240-44.

63 See Nicholas Wolterstorff, Divine Discourse: Philosophical Reflections on the Claim That God Speaks (Cambridge: CUP, 1995).

64 For a detailed articulation and defence of these claims, see Wolterstorff, Reason within the Bounds of Religion; Sloane, On Being a Christian in the Academy.

65 For a similar argument from a Roman Catholic perspective, see Corrine L. Patton, “"Should Our Sister Be Treated Like a Whore?": a Response to Feminist Critiques of Ezekiel 23' in The Book of Ezekiel: Theological and Anthropological Perspectives, ed. M.S. Odell and J.T. Strong (Atlanta: SBL, 2000): 221-38.

66 Gary Hall, 'Origin of the Marriage Metaphor', Hebrew Studies XXII (1982): 16971; Moshe Greenberg, 'Ezekiel 16: A Panorama of Passions' in Love and Death in the Ancient Near East: Essays in Honour of Marvin H. Pope, ed. J.H. Marks and R.M. Good (Guildford, Conn: Four Quarters, 1997): 143-50. 
rights over 'her' and her loyalty ${ }^{67}$ It is Yahweh who takes initiative in the relationship, has the resources and power to 'claim' Israel, and provides for 'her' in her life and flourishing. ${ }^{68}$ In light of this, as well as the relative roles of men and women in Israelite social and economic systems and the predominantly masculine language used for God, it is to be expected that Yahweh should be depicted as the husband in the marriage relationship. ${ }^{6}$ This is reinforced by the nature of covenant, which is probably best understood as a way of extending the kinship system to include those who are not biologically part of the family structure. In entering into 'covenant' with Israel, Yahweh is 'extending his kinship network', with the associated rights and obligations, to cover a nation which has no natural calls on his protection. ${ }^{70}$ Once again, given the theological and social worlds in which this notion operated, it makes best sense for Yahweh to be presented as the husband and for the people's failure to be described as [sexually] unfaithful). This is reinforced by the tradition, current in both ANE and Old Testament literature, of the city as the (chief) deity's consort. ${ }^{71}$ The metaphor is driven, then, not by misogynistic views of women's sexuality, but by a theological understanding of the nature of Jerusalem and of the relationship between God's people and their covenant lord. ${ }^{72}$

67 I use 'scare quotes' advisedly, as, while the language of possession is frequently used with reference to both God and Israel and husbands and wives, the primary issues relate, not to ownership and control, but to commitment and exclusivity. For refutation of the idea that men had 'property rights' in respect of their wives, see Christopher Wright, God's People in God's Land (Grand Rapids: Eerdmans, 1991): 183-221.

68 For the clear elements of grace in Yahweh's choice of Israel, see Joseph E. Coleson, 'Israel's Life Cycle from Birth to Resurrection' in Israel's Apostasy and Restoration: Essays in Honour of Roland K. Harrison, ed. A. Gileadi (Grand Rapids: Eerdmans, 1988): 237-50; M. G. Swanepoel, 'Ezekiel 16: Abandoned Child, Bride Adorned or Unfaithful Wife?', in Among the Prophets: Language, Image and Structure in the Prophetic Writings, ed. P.R. Davies and D.J.A. Clines (Sheffield: JSOT, 1993): 84-104.

69 See also Thomas Renz, The Rhetorical Function of the Book of Ezekiel (Boston: Brill, 2002): 77.

70 For this, see Scott Hahn, 'Covenant in the Old and New Testaments: Some Current Research (1994-2004)', Currents in Biblical Research 3.2 (2005): 263-92.

71 Block, Ezekiel, 468-69; Robert Carroll, 'Desire under the Terebinths: On Pornographic Representation in the Prophets-A Response' in A Feminist Companion to the Latter Prophets, ed. A. Brenner (Sheffield: Sheffield Academic, 1995): 299; Galambush, Ezekiel: 23-35.

72 See Ortlund, Whoredom. This perspective is also adopted, despite his distaste for Ezekiel, by Carroll, 'Desire under the Terebinths': 283, 288-89, 299. He is more accepting, however, of Brenner and van Dijk-Hemmes' reading of the metaphor in 
So too, Brenner and van Dijk-Hemmes' claims regarding the misogynistic nature of ancient Israelite society are implausible. Brenner's linguistic arguments are unsound, in the first instance because, as is now well known, etymology is no guide to meaning. Meaning is determined by linguistic usage which, in this instance, demonstrates that נִיקבד (neqevah, female) is simply used to specify a female creature or image, in the same way that זָז (zakhar, male) specifies a male one. ${ }^{73}$ However, even if etymology were a guide, as is occasionally the case with rare forms, the etymological data would undermine her case. ${ }^{74}$ Her cultural analysis of Israelite sexual ideology is similarly flawed: recent social scientific work on women in Israel suggests that the picture is much more variegated than Brenner and van Dijk-Hemmes claim, and that women's bodies played a positive as well as a negative role in the symbolic world of the OT. ${ }^{75}$ Given the importance of this linguistic and cultural context for her understanding of individual texts, these flaws significantly undermine her argument.

later work. See Robert Carroll, 'Whorusalamin: A Tale of Three Cities as Three Sisters', in On Reading Prophetic Texts, ed. Bob Becking and M. Dijkstra (Leiden: Brill, 1996): 67-82, esp. 76-77.

73 See the discussion of etymological fallacies in James Barr, The Semantics of Biblical Language (Oxford: OUP, 1961); D. A. Carson, Exegetical Fallacies (2nd ed.; Carlisle: Paternoster, 1996): 27-64; Grant Osborne, The Hermeneutical Spiral

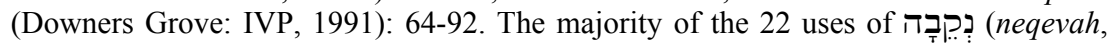
female) are found in the Pentateuch where it is paired with clear exception being Jer. 31:22. This, and other searches, were conducted using Gramcord (Bible Companion 1.6.4; GRAMCORD Morphological Search Engine 2.4cx; Loizeaux Brothers and The GRAMCORD Institute, (C) 1988-1998 and 1979, 1999).

74 Of the 18 uses of the verb root נקב (n-q-b) in both Niphal and Qal, 7 mean 'pierce' or 'make a hole'; the rest mean 'designate' or 'name', including 5 in Qal. The noun occurs rarely, and is of uncertain meaning, perhaps 'socket' (Ezek. 28:13, the NRSV translates it 'settings'). cf. William Holladay, A Concise Hebrew and Aramaic Lexicon of the Old Testament (Grand Rapids: Eerdmans, 1971): 244, who identifies 2 uses of the noun, the other being Josh. 19:33, where, however, it is most likely a place name. Would this derivation then mean that women are those 'designated', rather than orifices?

75 See Alice A. Keefe, 'Stepping In / Stepping Out: A Conversation between Ideological and Social Scientific Feminist Approaches to the Bible', Journal of Religion \& Society 1 (1999): 1-9. Now I must acknowledge that Keefe sees these more positive images as belonging to the pre-monarchic period; later depictions of women and their bodies she sees as much more negative and even misogynistic, of which Ezekiel is a clear instance. I am not convinced of the validity of some of her assumptions and methods and, as I shall argue below, a cavalier ascription of misogyny to Ezekiel such as hers is flawed; nonetheless, her more general point about the range of representations of gender in Israel and OT texts stands. 
Finally, Brenner's claim that pornography, understood as any sexual representation of the (female) form, is inherently patriarchal and misogynistic, is open to question. Apart from the theoretical weaknesses of her arguments, ${ }^{76}$ the very existence of both male and female homosexual pornography demonstrates that it cannot be understood just as an expression of male domination of females. ${ }^{77}$ Now, let me make it clear: I abhor pornography in all its forms. It demeans and objectifies men and women and belittles the gift of human sexuality. Equally, most pornography is produced by men for men and expresses and perpetuates a view of women which sees them as objects of male sexual desire and control. Unfortunately, objectifying depictions of female sexuality are not restricted to 'pornography' but are prevalent in many cultural depictions and descriptions of women and their bodies, to the detriment of both women - especially young and adolescent women - and men. ${ }^{78}$ In that respect feminist critique of pornography is on the mark. Where Brenner and van Dijk-Hemmes go wrong, however, is in their refusal to allow the intent of the (biblical) author any role in determining whether it counts as pornography or not, that being determined purely by its (possible) effects. ${ }^{79}$ This means any representation of the naked human form in art or literature is pornographic if it prompts sexual arousal (or can be envisaged as doing so). Given human predilections, this means that life drawing and surface anatomy texts can be lumped together with Playboy in the one amorphous conceptual category 'pornography'. That is not only an analytical confusion; it renders the notion of pornography void for vagueness. The purpose of a work must be a factor in determining whether it counts as a pornographic depiction of the female form. But as Brenner acknowledges, such was not Ezekiel's intent, which

\footnotetext{
76 See Carroll, 'Desire under the Terebinths', esp. 280-81, 287; Carroll, 'Whorusalamin': 78-80. It is worth noting that Carroll is sharply critical of the book of Ezekiel and its 'appalling representations of YHWH', for which see, 'Whorusalamin': 77-78; 'Desire under the Terebinths': 284, 292, 300.

77 See Wikipedia; <http://en.wikipedia.org/wiki/Lesbian_pornography>; <http://en. wikipedia.org/wiki/Gay_pornography $>$ [accessed Friday, 7 April 2006]

78 See Mary Stewart van Leeuwen, ed., After Eden: Facing the Challenge of Gender Reconciliation (Grand Rapids: Eerdmans, 1993), especially Part III. As the father of three adolescent women, these are messages I seek to expose and resist and counter.

79 This is consistent with their broader interpretive strategy which can be characterised as a reader-oriented reading 'against the grain' of texts (including cultural artefacts) that say see as inimical to women and their interests. As noted above, such readings necessarily diminish or discount the role of authorial intent.
} 
seriously undermines their counting Ezekiel 16 and 23 as pornographic texts with, in turn, significant implications for their general argument. ${ }^{80}$

\section{3:2 Their arguments and evidence}

Let us now turn to their arguments and evidence, beginning with van Dijk-Hemmes' claim that Ezekiel 23:3 is reminiscent of child sexual abuse. While it is understandable that this reference to childhood sexual activity raises the spectre of child abuse, such a reading would be foreign to both Ezekiel and his audience. One reason we find child sexual abuse so horrendous is the clear power differential between perpetrator and 'victim', and the inability of the child to make an informed and morally responsible decision about his or her sexuality. Whatever power differential existed between Israel and Egypt, however, has no bearing on this aspect of the metaphor, and Israel is presented as morally responsible from the beginning of her existence. We need to remember that metaphors are complex uses of language that do not map precisely onto their referents: central to their function as metaphors is the 'is and is not' nature of the language; and a key to their interpretation is figuring out how the metaphor does and does not refer, as well as how it shapes a view of reality. ${ }^{81}$ The notion that Israel's infancy was one of abused moral 'innocence' or immaturity requires the illegitimate 'mapping' of the metaphor onto Israel's history contrary to Ezekiel's intention and his audience's expectations. Ezekiel's concern is not, at this stage, with Israel's being burdened by slavery in Egypt, but with her history being shot through with infidelity from start to finish. This repeated motif in the book of Ezekiel would be familiar to his original audience and the book's original readers. ${ }^{82}$ Furthermore, the prophet's description of Israel as sinful from the beginning is true to the account as we find it in Exodus, including flagrant idolatry (Exod. 32; Num. 25) and a desire to depend on

80 I shall discuss the purpose of the graphic language of Ezekiel 16 and 23 below.

81 Sallie McFague, Metaphorical Theology: Models of God in Religious Language (London: SCM, 1983); Dan Stiver, The Philosophy of Religious Language: Sign, Symbol and Story (Cambridge: Blackwell, 1996): 112-33.

82 See his 'call' and the description of Israel as a 'rebellious house' (Ezek. 2:9, etc.) and his characteristic use of 'negative salvation history' in which stories that were traditionally used to speak of Yahweh's grace towards needy Israel are used to portray Israel's irremediable sinfulness (Ezek. 20). For this, and the distinction between audience and readers, see Renz, Ezekiel, esp. 41, 55, 72-93. 
Egypt's strength rather than Yahweh (Num. 11). ${ }^{83}$ Ezekiel is claiming that the nation Yahweh rescued from Egypt was a sinful nation, exemplifying from her origins the sins of which she is now guilty. The metaphor speaks, not of innocence abused but of sinfulness expressed. Child sexual abuse, then, does not pertain.

What clearly does pertain, however, is the claim that the language of Ezekiel's metaphor is crude and offensive. This is something that most translations sanitise-understandably so given the difficulty of rendering Ezekiel's language in a way that would be acceptable in a Church context. He speaks, for instance, of Jerusalem as having 'spread

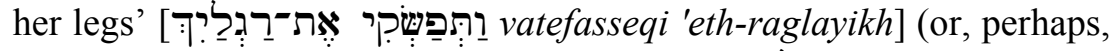
'opening her vagina', depending on the force of רְִּ [régél, foot, leg] in this instance) to every passer-by $(16: 25) .{ }^{84} \mathrm{He}$ also talks of her

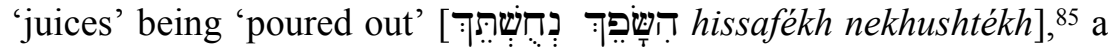
graphic portrayal of sexual arousal (16:36). ${ }^{86}$ It is not surprising that, given their experience of patriarchy in society and the Church, many women find this offensive, hearing echoes of male sexual abuse and exploitation of women. However, contrary to the pornoprophetic critique, this shocking imagery is not designed to titillate a male audience with a voyeuristic display of female nudity and sexual activity ${ }^{87}$ Rather, the audience in Ezekiel 16 is consistently addressed directly; ${ }^{88}$ Ezekiel 16 aims to shock, not titillate. Patton states, with reference to (other) pornoprophetic interpretations: 'Although these readings help to reveal why this text is so easily misread, they conceal the awareness of and horror at sexual violence in the original text.' ${ }^{99}$ She goes on to say that 'the metaphor of the punishment, the sexual violence that Shields and Weems find so offensive, also works only in

83 Coleson, 'Israel's Life Cycle': 242.

84 The Hebrew word רִּ (régél) meaning 'foot' or 'leg' can be used as a circumlocution for 'genitals' (Holladay, Lexicon: 332 ).

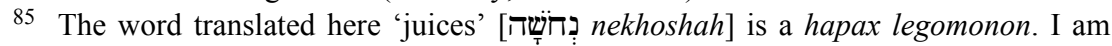
following the translation of Moshe Greenberg, Ezekiel, 1-20 (New York: Doubleday, 1983): 271, 285-86, as does Daniel I. Block, Ezekiel, in his comments on the verse (page 500), although he 'euphemistically' translates it as 'passion' (page 498).

86 The NRSV and NIV margin render this rather delicately as 'your lust was poured out'. Block, Ezekiel: 500, (overly) tactfully calls this 'almost pornographic' language.

87 Daniel Smith-Christopher, 'Ezekiel in Abu Ghraib: Rereading Ezekiel 16:37-39 in the Context of Imperial Conquest' in Ezekiel's Hierarchical World: Wrestling with Tiered Reality, ed. S.L. Cook and C.L. Patton (Atlanta: SBL, 2004): 141-57, esp. 146.

88 With the exception of v. 45 Ezekiel 16 consistently uses $2 \mathrm{fs}$ forms in referring to the woman.

89 Patton, 'Should Our Sister': 228. 
a culture in which men are also horrified by the image. This is not a text that portrays sexual violence against women as a good thing. The metaphor would not work if the male audience were not shocked.' 90 This does, of course, create problems for interpreters and especially translators-how can they render deliberately shocking and offensive language in a non-offensive manner?

For the audience to hear itself being described as 'spreading their legs' and 'pouring out their juices' on all manner of passers-by would have the same dramatic and shocking impact as Amos' turn to Israel in chapter 2, or Nathan's confronting 'you are the man' in 2 Samuel 12.91 Renz argues that the rhetoric of the metaphor confronts its exilic readers with Jerusalem's abhorrent behaviour, inviting them to distance themselves from sinful Jerusalem and agree with Yahweh's judgement on the city, and so themselves. ${ }^{92}$ With reference to the original audience, Patton argues: 'The metaphor works as part of Ezekiel's theology because the audience is forced to recognize their own responsibility, in the author's view, for this defeat, for these rapes and mutilations. In part, the author tells the male audience that [because of their sin] they are the agents of the rapes of their own wives, sisters, mothers. If that is not shocking, then the prophetic message fails.' 93 Perhaps we need to reconsider our implicit belief that the Bible is a 'nice' and 'comfortable' book, fit at all times for polite society. Sometimes it is not; when it deals with shocking and offensive realities, the text may embody that offence. We ought not to sanitise it or render it innocuous, but rather to ensure that its offence is rightly directedhere, not against women and their sexuality, but the people of God and their (our) flagrant infidelity to their (our) covenant partner.

Similar observations apply to the violence that the texts also embody. Here, again, we need to look squarely at the texts, see their stark, brutal violence and its association with female nakedness (Ezek. 16:37-42 and 23:22-28, 45, 46-47). This nakedness and violence, however, is neither pornographic voyeurism nor a means of expressing

90 Patton, 'Should Our Sister': 233.

91 Cf. Phyllis Bird, "To Play the Harlot": An Inquiry into an Old Testament Metaphor' in Missing Persons and Mistaken Identities: Women and Gender in Ancient Israel (Minneapolis: Fortress, 1997): Ch 10, 219-36, who makes a similar point in relation to the use of זָָָ (zanah, [sexually] unfaithful) for the people's sin.

92 Renz, Ezekiel: 77-78; cf. 88-89, 92-93, 144-45, once again drawing on the rhetorical distinction between audience and readers which is central to his argument.

93 Patton, 'Should Our Sister', 233. 
male domination; ${ }^{94}$ rather it reflects the very real horror of exile as both experienced and anticipated by Ezekiel. ${ }^{95}$ As Daniel Smith-Christopher notes, "The "humiliation" of "Jerusalem" as female must be directly connected to the ideology of, and practice of, Assyrian and Babylonian warfare... that suggested the imagery of stripping, and not a generally practiced punishment of adulterous women in Israel.'96 Similarly, Peggy Day argues that the stripping and execution of the 'whore' of Ezekiel 16 (and similar texts) does not represent the normal treatment of an adulteress, but refers to the punishment of covenant violation; failure to recognise this results from a misunderstanding of both the biblical and ANE evidence and the working of the metaphors and their rhetorical intent. ${ }^{97}$ Thus the violence of the texts reflects not standard patterns of behaviour in Israel, but the violent realities of war and exile, and is meant to generate a horror in the readers corresponding to the horror of exile. ${ }^{98}$ Hence pornoprophetic interpretations misread the metaphor in seeing it as justifying this as appropriate (sexual) violence in Israel's social world, rather than reflecting the historical realities of judgement on Israel's sinful violation of that world.

This raises the question of to what the metaphor refers. It seems to me that Brenner and van Dijk-Hemmes implicitly or explicitly see

94 As claimed by Brenner, van Dijk-Hemmes and others. See, for instance, Brenner, 'Pornoprophetics Revisited', 253, 266, 272; van Dijk-Hemmes, 'Metaphorization', On Gendering Texts, 173, 175; cf. Exum, 'Ethics', 248-49, 255-56; Gordon and Washington, 'Rape', 325; Magdalene, 'Ancient Near Eastern Treaty-Curses', 334-40, 347.

95 Smith-Christopher, 'Ezekiel in Abu Ghraib', 141-57.

96 Smith-Christopher, 'Ezekiel in Abu Ghraib', 153.

97 Peggy L. Day, 'Adulterous Jerusalem's Imagined Demise: Death of a Metaphor in Ezekiel XVI', Vetus Testamentum 50 (2000): 285-309; 'The Bitch Had It Coming to Her: Rhetoric and Interpretation in Ezekiel 16', Biblical Interpretation 8.3 (2000): 231-54; 'Metaphor and Social Reality: Isaiah 23.17-18, Ezekiel 16.35-37 and Hosea 2.4-5' in Inspired Speech: Prophecy in the Ancient Near East, ed. J. Kaltner and L. Stulman (London: T\&T Clark, 2004): 63-71. She specifically refutes the dominant tradition of interpretation which sees the woman as receiving the normal punishment meted out to an adulteress in Israel, as reflected in Swanepoel, 98; Walther Zimmerli, Ezekiel 1: A Commentary on the Book of the Prophet Ezekiel, Chapters 1-24 (Philadelphia: Fortress, 1979): 346; Ralph Klein, Ezekiel: The Prophet and His Message (Colombia: University of South Carolina Press, 1988): 85; Lamar Cooper, Ezekiel (Nashville: Broadman \& Holman, 1994): 174; Daniel I. Block, Ezekiel, 502-3; and even Renz, Ezekiel, 146, 193, 196-97, although he believes there is a mix of the literal and metaphorical in the description of Jerusalem's destruction.

98 Smith-Christopher, 'Ezekiel in Abu Ghraib': 155. 
Israelite sexual ideology as a key referent of the text. ${ }^{99}$ The text refers to this patriarchal ideology either indirectly, by way of its influence on the metaphors and their workings, or directly, by way of its calling for women to submit to men in the same way that the city is meant to submit to her 'male' overlord, Yahweh. The validity of that claim, in turn, depends on whether the text does, in fact, directly address women and their sexuality, and in a manner different to the way it addressed men. So, finally, let me address the claim that the metaphors (say in Ezek. 23:10 and 48) do directly address women and their sexuality, and allow an 'escape' for men that is not available to women. Corrine Patton identifies three key flaws in the case, the last of which is our focus: the 'assumption that the female object is controlled', the failure to address the historical context of the language and metaphor, and the idea that verses 10 and 48 show that 'this text is also being used to substantiate treatment of real women'. ${ }^{100}$ She argues that verses 10 and 48 do not address real women in Israelite society but the metaphorical woman - the (predominantly male) audience - confronting them with their own sin. This, far from allowing them to displace their shame onto women and so escape the indictment of the text, is a particularly confronting and humiliating way of presenting to the men in the audience their responsibility for the violence the city endured. ${ }^{101}$ Furthermore, we need to recognise the significance of Ezekiel's context. His ministry, coming as it does after the first deportation,

99 Pace Carroll, 'Whorusalamin': 70, who argues that 'postmodern' readings such as theirs focus on the signifier not the signified. Rather, their concern is with both, but they focus on the signified as a sexual ideology rather than those historical phenomena which are the main concern of 'modernist' historical-critical scholarship.

100 Patton, 'Should Our Sister': 228.

101 Patton, 'Should Our Sister': 231-32; see also Renz, Ezekiel: 89. This issue of shame, whilst raised by Brenner and van Dijk-Hemmes, is a major focus of Galambush's analysis of Jerusalem in the book of Ezekiel, which informs their work. She argues that Yahweh's honour is impugned by the 'infidelity' of the city which, in turn, threatens all men with shame. The pornographic depiction of the violent treatment of the city serves to re-establish his control and shore up the threatened patriarchal order. See Galambush, Ezekiel, esp. 23-35, 83-88, 102-5, 109, 117, 120, 124-25, 15657, 159-63. Patton's rejection of this understanding of shame and its relation to the metaphor is reinforced by Margaret S. Odell, 'The Inversion of Shame and Forgiveness in Ezekiel 16.59-63', JSOT 56 (1992): 101-12; Keefe, 'Stepping In / Stepping Out': 114; Johanna Stiebert, 'Shame and Prophecy: Approaches Past and Present', Biblical Interpretation 8.3 (2000): 255-75; Jacqueline E. Lapsley, 'Shame and Self-Knowledge: The Positive Role of Shame in Ezekiel's View of the Moral Self' in The Book of Ezekiel: Theological and Anthropological Perspectives, ed. M.S. Odell and J.T. Strong (Atlanta: SBL, 2000): 143-73. 
follows a long history of recalcitrance and resistance to the prophets. Indeed, these metaphors are placed after his visionary encounter with the flagrant sins of Jerusalem in, say, Ezekiel 8. In light of that context perhaps Ezekiel needed to shock his audience in an attempt to awaken them to their plight. ${ }^{102}$

Thus we have seen that the main lines of argument used to support pornoprophetic readings of Ezekiel 16 and 23 fail. This, coupled with crucial problems with methodology and assumptions underlying the claims, undermines the force of their case. We have also seen that the texts are deliberately shocking in their portrayal of Jerusalem's sin, an uncomfortable reality that we must address. One way we must do so is to seek to ensure that their offence is rightly directed. While an ideological reading of these texts is unfounded, it should alert us to the possibility of our ideological distortion of these texts. Ezekiel 16 and 23 could, I suppose, be used to victimise and stigmatise women, although I have found no evidence of this. ${ }^{103} \mathrm{We}$ need to be careful, not just to avoid such misogynistic abuse of the texts, but also to ensure that our audience does not misunderstand them as being misogynist. This may be a difficult task, especially given the deliberately shocking nature of the material, but is necessary if these powerful texts are to confront the people of God today.

\section{Conclusions}

The nature of the pornoprophetic criticism of Ezekiel - the claim that Ezekiel 16 and 23 are examples of 'aberrant textuality' promulgating violent, misogynistic views that must be resisted and rejected-is clear. It is also clear that, while Brenner and van Dijk-Hemmes' arguments may work within a particular interpretive framework, they are only

102 Christopher Wright, The Message of Ezekiel: A New Heart and a New Spirit (Leicester: IVP, 2001): 127-29. Alternatively, reading it from the point of view of an exilic readership, the shock and outrage that the texts evoke calls them to judge their own behaviour and accept Yahweh's judgement as just (Renz, Ezekiel: 77-78, 144-45).

103 The claim, reiterated by Brenner and van Dijk-Hemmes, that these texts and the religious ideology they express foster (sexual) violence against women is akin to the unsubstantiated claim that (conservative) religion is to blame for the violence and wholesale slaughter of the last century, a claim clearly refuted in Os Guinness, Unspeakable: Facing Up to Evil in an Age of Genocide and Terror (New York: HarperCollins, 2005): 34-46. This is not to say that biblical texts have not been illegitimately used to foster patriarchal interests. Clearly they have; but I have found no evidence that these texts have been so used. 
justified from within that perspective. Given, then, that their methods and assumptions are open to serious criticism, there is no good reason to accept their pornographic reading of texts such as Ezekiel 16 and 23. Indeed, given the implausibility of Brenner and van Dijk-Hemmes' key claims when assessed independently of their flawed methods and assumptions, we have good reason to reject their pornoprophetic reading of the metaphors. The texts do not articulate and perpetuate misogynistic sexual politics; they certainly give no comfort to contemporary abuse of women or domestic violence. They are violent and offensive texts, but that violence is not directed against women, but serves to highlight the offensiveness of $\sin$ and the reality of judgement. Texts such as these were used by God to confront his erring people with the horror of their sin and its consequences. Read in that light, avoiding the errors of either wrongly directing the texts' indictment to women and their sexuality, or seeking to soften and sanitise deliberately appalling texts, we too are confronted with the horror of $\sin$ and its consequences. These texts, far from vitiating the value of the prophets for Christian theology and ethics, demonstrate that value with their uncomfortable and confronting rhetoric. I am not sure that my analysis will convince any proponents of 'pornoprophetics'. I hope that it allows us, if not to like the texts, at least to understand them and what they are about. And that, perhaps, is the best that any of us can hope for. 